\title{
Is meeting the needs of tourists through ethnic tourism sustainable? Focus on Bali, Indonesia
}

\author{
Yoko Mayuzumi ${ }^{1} \mathbb{C}$
}

Received: 15 July 2020 / Accepted: 26 March 2021 / Published online: 16 April 2021

(c) The Japan Section of the Regional Science Association International 2021

\begin{abstract}
The United Nations' World Tourism Organization (UNWTO) states that "it is necessary to respect the host community's socio-cultural authenticity and protect cultural heritage and traditional values" to facilitate sustainable tourism development. Sustainable Tourism Indicators (STI:2004) show that sustainable tourism development promotes economic, social, environmental, and cultural sustainability. Therefore, it is essential to understand the resident situational context and safeguard "the happiness in the society that hosts tourism". Tourism that uses cultural heritage as a selling point includes ethnic tourism. Cultural heritage and traditional values are attractive sales resources for generating tourism revenue. This point may be detrimental to the residents because they damage the culture and traditions in multiple economic, social, and cultural aspects of economic, social, and cultural. Ethnic tourism must be sustainable without destroying the local culture and traditions. This study aims to analyze whether the requirements for sustainable tourism development that the UNWTO outlined met by the ethnic tourism that Bali develop. Ethnic tourism has grown in Bali since it first began in the 1970s; many tourists have visited the region and have been deeply impressed by its traditional arts and crafts and hope to bring them back. This phenomenon has generated an immense demand for taking home back pieces of traditional Balinese art and crafts and bolster the mass production of traditional art and crafts sold as souvenirs to tourists. Regarding this situation, positive and negative effects on the culture and traditions of the region by overtourism through ethnic tourism need to be determined. This study focused on traditional Balinese sculptures and paintings and conducted surveys to examine the consciousness of craftsmen involved in traditional crafts to reveal the influences of tourism on traditional culture in Bali. The hypothesis of this study was as follows: Ethnic tourism that attempts to sell traditional culture to the tourist does not satisfy the requirements for the development of sustainable tourism development leading to happiness in the society hosting the tourism. As a preliminary survey, I planned interviews to obtain the craftsmen's opinions and to devise questions for subsequent
\end{abstract}

\footnotetext{
This survey is conducted jointly with Indonesian government-approved environmental foundation "Bali Biodiversitas".
}

Extended author information available on the last page of the article 
questionnaires. I conducted the interviews with craftsmen in August $2019(n=4)$. Subsequently, I conducted the questionnaire survey for craftsmen (wood-carving and painting) in August and September 2019 and January $2020(n=103)$. The questionnaires were analyzed using simple tabulation, comparison of means, factor analysis, and multiple regression analysis. Additionally, as a survey to understand customers' needs concerning traditional culture, I conducted an interview survey for tourists in August 2019. This survey sought to identify why they purchased wood-carvings and paintings $(n=9)$. These surveys showed that nearly half of the craftsmen involved in traditional crafts lost their employment because of ethnic tourism. The hypothesis was verified because the situation did not achieve sustainability for maintaining the livelihoods of the craftsmen, who also play a role in the transmission of traditional culture. It was unclear whether the life with ethnic tourism that eliminated their position would lead to happiness.

Keywords Ethnic tourism - Tourism anthropology · Cultural heritage · Consciousness survey $\cdot$ Bali $\cdot$ Traditional culture $\cdot$ Paintings $\cdot$ Wooden craft

JEL classification $\mathrm{R} 11 \cdot \mathrm{Z} 11 \cdot \mathrm{Z} 32$

\section{Introduction}

\subsection{Research Background: ethnic tourism and Bali Island}

Bali province in Indonesia is a small island with an area of 5,632.86 km. Not only "South Island" and "Beach", but also it attracts tourists all over the world with the impression of "rich nature", "the island where many kinds of gods live", and "the island of culture and art". Indonesia is the largest Muslim country globally, with Muslims accounting for $88.1 \%$ of the total population. On the other hand, in Bali, more than $90 \%$ of the island's total population is Hindu, and they are called Balinese Hindus. Furthermore, Balinese Hinduism is a particular case of inheriting the original Hindu culture, although it is called soft Hinduism because of its milder discipline, unlike Indian Hinduism.

Tourism in Bali began in the 1920s during the Dutch colonial era. After Indonesia got independent as a nation, President Suharto's in 1972 made tourism development a top priority for economic growth in Bali. The story of the tourism industry in Bali had led to relieving extreme poverty for the most impoverished region in Indonesia. As the number of foreign tourists increased, the tourists, mainly Westerners, had deep interests in Balinese natural unique resources and traditional culture, rather than the Indonesian government's closed rich resort. Western tourists had moved to more attractive targets, private beach and luxury hotel enclosed had become the destination for tourists having some limited purpose. Many foreign tourists like western had admired cultural and ethnic tourism. Tourism in Bali is currently being expanded on two different axes, selling ethnic culture and beach life. Ethnic tourism involves the first experience and the meet of another culture to provide tourists with 
a more "intimate" and "authentic" experience (Greenwood 1982; Klieger 1990). According to Weiler and Hall (1992), ethnic tourism defines as "travel motivated by the tourist's desire for direct, genuine and intimate contact with people of different ethnic and cultural backgrounds from the tourist". And the purchase of souvenirs is an opportunity to experience different cultures, and through this act, tourists can form a space for cross-cultural and social negotiation.

\subsection{Research background: sustainable tourism and Bali Island}

As a hot topic of international tourism before the occurrence of COVID-19, while the number of tourists worldwide has increased in recent years, including in Bali, over-tourism (an old concept is also called tourism pollution) is focused as a problem. There are reports on many issues that have a significant impact on the sustainability of tourism activities. These are the problem of overuse of toilets and aging of accommodation facilities and graffiti on cultural properties, destruction to natural ecosystems due to step on by a large number of tourists. Tourism pollution means the concentration of tourists and the occurrence of problematic events there. The United States and the western countries that the tourism pollution has occurred earlier get the following advice from the United Nations World Tourism Organization (UNWTO), "There is 'Carrying Capacity' in the tourist area. Therefore, it is necessary without giving damage to the natural environment, economy and social culture, at the same time, the maximum number of tourists that can visit at one time should be adjusted so as not to reduce the satisfaction of tourists". The UNWTO has also proposed guidelines for solving tourism pollution and published the Guidebook for Sustainable Tourism Indicators (STI:2004). The STI set the following three points. (1) (Environment) Optimizing the use of tourism resources, (2) (Society) Respecting the socio-cultural authenticity of the receiving society, (3) (Economy) Evaluation indicators aiming for guarantee long-term economic activities. And more, the management is added to the 4th. Based on these viewpoints, it is desirable to add the perspective of "sustainable tourism" and set a policy that considers the actual conditions of each region. Regarding the concept of over-tourism in STI, although STI focus on first for the environment and second for society and culture, they do not fully address the second. One point included in the second is "about the happiness to the receiving society". This point is a problem concerning tourism's impact on the community (local benefits related to tourism). For example, many articles have reported issues with manners by tourists, traffic congestion, and excessive access to residents' houses (intrusion into living customs). The recent report of "Survey on the ideal way of sustainable tourism policy" by the Japan National Institute of Land, Infrastructure, Transport and Tourism (2019) shows a leading example of efforts to examine "about the happiness to the receiving society". There are three examples of tourism indicators that have been worked on (Kenta 2019). These include the DIT-ACHIEV (Dublin Institute of Technology ACHIEV Model), a guideline for Ireland's sustainable model formulated in 2008, and the KI-TOMM (Kangaroo Island, Kangaroo Island, Kangaroo Island, Australia, composed in 1996. Tourism Optimization Management Model), and the Sustainable Tourism Zone of the 
Caribbean established in 2005. These are indicators set in consideration of sustainability from the perspective of both residents and tourists. These cases are one of the few advanced efforts.

In 2012, "Jatiluwih" in Bali has been registered as a World Heritage Site in the rice terraces' rural landscape. Visiting a large number of tourists has caused severe problems to the local community. For example, many residents are converting their farmland into accommodation according to the growing demand for lodging by tourists. Or tourists are encroaching on local farmland and destroying the footpaths between rice fields without permission. Thinking about these problems seriously, the local administration has launched a policy that recommends agriculture and tourism to develop together. Specific initiatives include promoting home-stay guesthouses run by local residents as opposed to hotels built by outside capital, charging fees for tourists to enter the village and using the income for the village, and charging fees for waste disposal of leftover food by tourists from the cafeteria. In the future, in such places, detailed guidelines on sustainable tourism that care about the happiness of the community, rather than not only focusing on economic benefits for tourism revenue, need to be formulated in regional policies. Besides, to coexist with COVID-19, tourist destinations should consider sanitary management and disease prevention measures. At the same time, it is necessary to increase the attractiveness of tourism in areas that are currently unpopular or where outdoor tourism is possible. This view will also become a universal recognition of sustainable tourism in the future.

\section{Literature review on ethnic tourism}

\subsection{Transformation of traditional culture}

It is said "it is necessary to respect the host community's socio-cultural authenticity and protect cultural heritage and traditional values (UNWTO 2004)" for practicing sustainable tourism development. What this means is that "even if there is a willingness to be a target for tourism, they must avoid voluntarily changing their culture to make it a target for tourism" (Yoshinori 2011). The value of "The culture being the object of tourism" is different between those who run a tourism business and those who are indifferent to tourism and those who want to have it but do not have the opportunity to have a business (Kayoko 2004). When a business perspective adds, a marketing strategy is needed, and it is necessary to pay attention to the needs of tourists and meet their expectations. However, this has the following adverse effects. People in the community make the traditional rituals more beautiful, sometimes they try to change them, and they make large-scale forms so that tourists will not be disappointed. As a result, all attractions to tourists become artificial, so tourists are not looking at the original foreign culture itself, but only at what is there for tourists (Boorstin 1962). Tourists' expectations make arranging many traditional things or created newly, even though it shows tourism as "traditional" (Toshiharu 2002; Hobsbawm and Ranger 1983). There are other reports. Other ethnic groups have designed the presentation of ethnic culture such as traditional dance formed by being separated from the original context is a well-known "tourism" even if it is 
improper (Kazuya 2013). Also, rather than simply discarding the culture presented in such a form as a fake, there are opinions that it should be regarded as a "directed real thing" (Mac Cannel 1976) or as a "tourism culture" that is different from traditional (Kazuya 2013; Kayoko 2004). Tourists will not complain about the provision of "structured performances" at their side. However, they care about the quality of the performance itself. And a study has reported that tourists feel more "trustworthy" about a performance when the audience is small (Brunner 2004).

\subsection{Reviews focusing ethnic tourism and traditional culture in Bali}

McKean (1973, Quoted in Michel Picard (1990)) has begun studying tourism in Bali at an early stage and presented a hypothesis about the impact on traditional culture caused by tourists as follows.

1. Change is brought about by an external, usually superior, socio-cultural system that invades a weak, passive culture.

2. Change is generally disruptive to indigenous cultures.

3. 3 The direction of change is the transition to a homogeneous culture that embraces ethnic and regional identities.

McKean says, "it is easy to introduce new ideas in tourism activities, and new things are easier to sell. But tourists would like to see ancient traditions permanently preserved, especially in the theater and plastic arts. If Bali were to remake them in a modern way, many would not visit in this way. Both cultural preservation and economic necessity push the Balinese to preserve the traditional skills of their carvers, instrumentalists, and dancers". McKean mentions this as pointing out that "even if the tourism development in Bali is undergoing a socio-economic change towards modernization, it is going hand in hand with traditional culture, reinforcing the process of preserving, reforming and re-creating tradition" (Smith and Hiroshi 1991). There are research reports agreeing with McKean's statement of "reinforcing the process of preserving traditions, reforming, and recreating". According to Shinji (2001), "Tourism development in Bali doesn't destroy traditional culture, but rather contributes to the reconstruction of traditional culture". There is a consideration that traditional culture, especially traditional performing arts, has been preserved in tourism development. According to Geria (1996), he mentions that the development of the tourism industry has two impacts on the culture of Bali. On this positive side, it reveals that the development of the tourism industry in Bali has preserved the traditional culture and performing arts of Bali and developed it and creates new culture and art. On the negative side, as Kelly (1997) also mentions, it raises concerns that tourism development could sometimes destroy a traditional culture. Mass tourism, which many people visit, has made a shift and change in local culture (Mubashar 2011).

The impact of tourism development on traditional culture has positive and negative aspects, but it is the negative aspect that is serious for sustainable development. There are severe warnings about the negative aspects. Nezar (2001, 2004) has discussed the "demise of tradition". This word means "death of tradition", as 
disposability of a valuable heritage, which he describes as follows, "Which means the death of its meaning and the use as a container of authenticity as a valuable heritage or preservation" (Nezar 2001, 2004). Gede Kresna, one of the famous Indonesian architects from Bali that owns an architecture consultant company called "Rumah Intaran" in North Bali, has said, "Tourism should be returned to the community".

\section{Development of ethnic tourism in Bali and cultural heritage protection policies related to traditional handicrafts in Indonesia}

\subsection{Traditional culture affected by development of ethnic tourism in Bali}

Paintings, sculptures (wooden and stone carvings), weaving, knitting, fittings (gates and doors), etc., have been passed down as the culture of traditional crafts in Bali. These shapes and woven textiles represent the embodiment of Hindu doctrine, approximately $90 \%$ of the island's population worship, and show the island's unique patterns and the richness of Bali's nature. As ethnic tourism has developed in Bali in the 1970s, many tourists visited the island and deeply impressed the traditional art and crafts. This point has generated an immense demand for pieces of traditional Balinese art and crafts, which has bolstered the production of pseudo-traditional art and crafts to sell as souvenirs to tourists. As a result, small business of traditional crafts has developed into a souvenir industry, which has grown significantly since the 1980s. For growing up as a souvenir industry, the production site needed many craftsmen. Traditional crafts have been worked on and passed down mainly at the local village level. This small economic boom has occurred in the traditional crafts industry. However, to date, traditional craft workshops that have failed to meet the changing needs of repeat customers and enhance their value as souvenirs have been forced to lose work one by one. Also, even the artist, who is originally the successor of traditional crafts, has been forced to stand on same level as new craftsman, and some have to lose his job together. Tourists want to buy traditional Balinese art and crafts through their egoism of self-ownership, but they sometimes cannot judge the quality of goods, good or not good, and like cheaper ones. Meeting to needs of tourists seems to make a barrier for the Balinese traditional craft industry to survive. This situation might increase the possibility of the disappearance of Balinese original traditional culture itself for tourism.

\subsection{Cultural heritage protection policies related to traditional handicrafts in Indonesia}

The traditional handicrafts that are the subject of this study can regard as Indonesia's tangible ethnic and cultural properties. The industries relate to traditional handicrafts in Indonesia contribute significantly to the country's economy. For example, in 2017, the most famous handicraft industry, batik and textile products had a total export value of US\$151.7 million, or Rp 2.1 trillion (Antara-news, May 5, 2017). In 
other words, the traditional handicraft industry in Indonesia is a significant business for both the country and the craftsmen and is a target that should protect sustainably. However, the cultural heritage protection policy related to traditional handicrafts in Indonesia is not functioning well. First, I would like to introduce the procedure for the protection of cultural properties. To help readers' understand, I will show the Japanese cultural heritage protection policy first, and then will show and compare the efforts of Indonesia.

In the Japanese policy for the protection of cultural heritage, the Minister of Education, Culture, Sports, Science, and Technology registers objects that permit to be necessary, based on detailed research by the "Specialist Committee" of the Council for Cultural Affairs, which is composed of members of well-informed people. There is a similar process at the local self-government level. Cultural Properties Protection Specialist researches the objects that permit valuable, and local self-government registers them as cultural heritages. It also defines that all citizens have to protect cultural heritage and pass them on to the next generation, and this program operates with public expenses. On the other hand, Indonesia's cultural property protection policy is different from that of Japan.

There is a law to protect the intellectual property rights of citizens working in traditional handicrafts, called "Undang-Undang Nomor 28 Tahun 2014 Tentang Hak Cipta (UUHC)", Law No. 28 (2014) on Copyright. The sixth of the nine types of works stipulated in the first paragraph of Article 59 of this document is "all forms of art, including the art of painting, drawing, sculpture, calligraphy, and collage", traditional crafts that are the subject of this study. The UUHC aims to protect creative works on these items. Copyright registration is to be performed at the Directorate General of Intellectual Property (DJKI), which is currently under the Ministry of Justice and Human Rights jurisdiction, by the persons themselves who should hold the copyrights. For reference, criminal sanctions for copyright infringement are usually punishable by up to 10 years imprisonment and may or may not impose a fine of up to 4 billion rupiahs. In Indonesia, currently, registration of a work is not a duty of the creator or copyright owner. Besides, many of the copyright organizations in Indonesia are related to music video and software, and there are not copyright organizations for traditional handicrafts. Unfortunately, the policy for protecting the intellectual property rights of traditional handicraft workers is still not enough. And, as mentioned above, copyright registration is not effective unless it is applied for by themselves. In other words, there is no protection system as shown in Japan, where experts research and judge the work, recommend it as an object of cultural property and register it unless the copyright holder himself applies for it.

It is not that the Indonesian government has not been making efforts to protect cultural heritage. Since there is no proper documentation about the national policy on this, the Author conducts an interview with "I Made Sumantra, M.S.I", a professor at the Indonesian Institute of the Arts Denpasar (ISI) of Indonesia's national arts university, who is an expert on the Indonesian government's art policy (2021.1.20).

"In the 1980s, there was a government-led world art exposition including an exhibition of traditional handicraft, but no such program now. At present, the only way to implement such activities is to take private efforts. Also, at that time, there was a special program to award art prizes to the creators of works, including 
traditional crafts, and winners of this prize supported the growth of traditional crafts. In the traditional crafts focused on in this study, the only well-known person of the traditional crafts sector in Indonesia is Mr. "I Made Ada", a woodcarver and creator of the Garuda, the national emblem of Indonesia, from Pakdui village near Tegalalang in Ubud of Bali. His work was purchased and placed in the Indonesian Presidential Palace and purchased by the US too. President Ronald Reagan and was awarded the Kharisma Society Indonesia Prize in 1995. The World Intellectual Property Organization (WIPO) collection in Geneva, Switzerland, owns the "I Made Ada"s' carving.

On the other hand, as Bali province, independent policies, the provincial governor Mr. "Ida Bagus Mantra" implemented a policy of art protection in 1976. He built the Ardha Candra Art Center and proposed a strategy of art awards, including traditional crafts. This experience had brought Bali to the attention of the international market as the center of art, including crafts, in East Indonesia. Today, however, there are no art prizes or supportive measures for protecting traditional crafts by the government. In rare cases, the private sector is involved; for example, about support for the arts, tobacco industry associations, including Philip Morris, currently provide".

Furthermore, in this study, the facts that indicate the lack of protective measures for traditional craftsmen at the Indonesian government's work site should be confirmed. The following are the results of an interview (2021.2.3) with Mr. "I Nyoman Darmawan", the son and successor of those as mentioned above, "I Made Ada".

"From 1980 to 1996, we got many invitations by the government to promote traditional crafts as a cultural activity of Indonesia. In particular, he received many invitations from Indonesian embassies abroad. Whenever essential government officials from other countries visited, the governors introduced him to them. This experience led to private connections and business opportunities for him. And, the government gifted his Garuda works as souvenirs to essential guests from other countries. Also, government officials were willing to buy them. Even now, orders are still received occasionally because of that. During the period mentioned above, the government also focused on promoting tourism in Bali itself, with the concept of "cultural tourism". In cultural tourism, the selling point was the lifestyle of local people, whose culture is a part of their daily lives.

During this period, the government applied for his patent. As a result, it was famous worldwide, and only I Made Ada got the license from WIPO (World Intellectual Property Organization). Later, when Megawati was President, there was the same kind of generous support from the government. Whenever essential government officials from foreign countries came to Indonesia, the governors invited him and introduced him to them. After President Megawati retired, there are no more invitations from the government until now. Nowadays, traditional craftsmen have to promote their works by themselves and apply for patents to protect their works. For promotion, they use social networking sites such as Instagram. Their lives are not wealthy. They do not profit because they are not looking for only income but concentrate on making high-quality products. The only ones who are making money are the middlemen gallery owners, and the reality is the craftsmen are not profitable".

(Interview with I Made Ada at his workshop, 2021.2.3). 
Based on the interview content, it is not hard to imagine how the lives of notfamous artisans are and the protection of their works treat because the most famous traditional craftsman in Indonesia is in such a situation. In other words, most of the traditional craftsmen are not protected, at least not by the government.

\subsection{A survey focusing on traditional crafts}

In this study, I focus on the fact that the business of ethnic tourism utilizes traditional crafts and also there are issues in the protection of traditional crafts. I plan to survey the consciousness of craftsmen. Among the traditional crafts, they are focusing on paintings and wood-carvings, which tourists often purchase. Interviews with tourists will also conduct to know the purpose of purchasing by tourists. The survey has a subject of showing whether the influence of ethnic tourism has forced field craftsmen to damage their traditional culture. From the perspective of "the wellbeing of the society that accepts tourism", this paper will provide quantitative information on both the negative and positive impacts of ethnic tourism on preserving traditional crafts.

\section{Hypothesis and purpose in this study}

This study set the hypotheses as follows.

"Ethnic tourism, which attempts traditional culture as for sale to the tourist, does not satisfy the requirements in sustainable tourism development concerning realizing happiness in the society that hosts tourism".

Both negative and positive impacts of using traditional culture for tourism business will be analyzed and revealed from the craftsmen's consciousness. It will then be determined if the culture and traditions of the craftsmen are protected. From the results, it will verify whether ethnic tourism in Bali meets the requirements of sustainable tourism development or not. Furthermore, the discussion of the findings will serve as a basis for considering sustainable cultural conservation measures, which will lead to the sustainable development of ethnic tourism.

\section{Research methods}

The surveys, focusing on the Ubud district called the art village inland of Bali, are conducted for those involved in traditional craft products (wooden carving and painting) of traditional culture developed in village units. The wooden carvings, the village that deals specifically with the Komodo dragon and other indigenous species in Indonesia, accepts the survey. As for the paintings, the village that deals with the concept of "Ketut style" paintings based on the old traditional lifestyle accepts for the survey. 
It is helpful to prepare questions with various viewpoints and find out the trends by analyzing using multivariate analysis in consciousness survey. It needs to conduct a preliminary survey to obtain the views of local people on the traditional culture.

It conducts interviews with the local craftsmen in August $2019(n=4)$. The author uses the results to develop questions for the following consciousness survey. Subsequently, it conducts a questionnaire for traditional craftsmen (wooden carving and painting) in August and September 2019 and January $2020(n=103)$. The questionnaire data are analyzed using simple tabulation, comparison of means, factor analysis, multiple regression analysis, and verified hypotheses. Additionally, to understand customers' needs concerning traditional culture, another preliminary interview survey for tourists is conducted in August $2019(n=10)$.

\subsection{Interview for craftsman involving in art creation}

It is necessary to know more detailed consciousness about traditional culture. More interviews have with those who continue to create and sell their work as artists. In the interview survey, I ask their purpose and motivation to continue a craftsman. I prepare the following questions to obtain their thoughts.

1. Motivation to become a craftsman.

2. How to develop skills.

3. Vision for the job.

4. The existence of work helpers (who, how many, and what process they will be working on).

5. How to consider women's participation in work.

6. An obsession with craftsmanship.

\subsection{A questionnaire for craftsmen in wooden carving and painting}

There are four groups of questions to find out about the consciousness of the craftsmen, as follows: (1) Face Sheet (2) Characteristics of traditional crafts with handling; (3) Economic viewpoints; (4) Needs for Traditional Craft; and (5) How to think about the traditional culture in Bali. About this consciousness, I set a total of 31 questions as follows (Table 1). Except for the "Face sheet" group of questions, these four groups of questions are in an eight-point response format using a Likert scale from "applicable" to "not applicable". I analyze the data using simple tabulation, comparison of means, factor analysis, and multiple regression analysis.

\subsection{Interview for tourists who bought traditional crafts}

I conduct Interviews with tourists who are buying a souvenir of traditional crafts. In this survey, the interviewer waits in front of a shop selling crafts in Ubud traditional market in Bali and ask responses from those who purchased crafts. It takes 
Table 1 Contents for Questionnaire survey for craftsmen of woods carving and painting

\begin{tabular}{|c|c|}
\hline 1. Face sheet & 1-f Physical supporting by family \\
\hline 1-a Sex & 1-g Selling style \\
\hline 1-b Age & 1-h Type of product \\
\hline 1-c Name of vllage & 1-i Period of involvement as a craftsman \\
\hline 1-d Types of traditional crafts & 1-j Whether to continue as a craftsman \\
\hline 1-e Working method & 1-k Current job \\
\hline $\begin{array}{l}\text { 2. Characteristics of traditional crafts that I am } \\
\text { handling }\end{array}$ & 3. Economical perspective \\
\hline $\begin{array}{l}\text { 2-a. The items I am dealing with are traditional } \\
\text { crafts from Bali }\end{array}$ & 3-a. Amount of income from my job is enough \\
\hline $\begin{array}{l}\text { 2-b. The item I am handling is not a traditional } \\
\text { Bali, but a souvenir }\end{array}$ & 3-b. My work can support my family enough \\
\hline $\begin{array}{l}\text { 2-c. The products I am dealing with require a high } \\
\text { level of craftsmanship }\end{array}$ & $\begin{array}{l}\text { 5. The way of thinking about the traditional craft } \\
\text { culture in Bali }\end{array}$ \\
\hline $\begin{array}{l}\text { 2-d. I have a high-level skill in making the items I } \\
\text { am handling }\end{array}$ & $\begin{array}{l}\text { 5-a. Traditional crafts have the spirit of Balinese } \\
\text { people }\end{array}$ \\
\hline $\begin{array}{l}\text { 2-e. Almost everyone in the village is involved in } \\
\text { the production of the objects I am dealing with }\end{array}$ & $\begin{array}{l}\text { 5-b. Traditional crafts should be designed to show } \\
\text { the characteristics of Bali }\end{array}$ \\
\hline $\begin{array}{l}\text { 2-f. Concerning the items I treat, every craftsman } \\
\text { has a high degree of pride in treating it }\end{array}$ & $\begin{array}{l}\text { 5-c. I think traditional crafts in Bali are prospering } \\
\text { now }\end{array}$ \\
\hline 4. Needs for Traditional Craft Products & $\begin{array}{l}\text { 5-d. I think the future of Bali traditional crafts will } \\
\text { prosper }\end{array}$ \\
\hline $\begin{array}{l}\text { 4-a. Currently, the items that I handle are in } \\
\text { demand as souvenirs from tourists }\end{array}$ & $\begin{array}{l}\text { 5-e. I want to protect the traditional craft culture that } \\
\text { symbolizes Bali }\end{array}$ \\
\hline $\begin{array}{l}\text { 4-b. The style of the item I am handling may be } \\
\text { changed according to the needs of tourists }\end{array}$ & $\begin{array}{l}\text { 5-f. I welcome the change of Bali traditional crafts } \\
\text { according to the needs of foreign tourists }\end{array}$ \\
\hline $\begin{array}{l}\text { 4-c. I should keep the traditional style of Bali } \\
\text { without being confused by the needs of tourists }\end{array}$ & $\begin{array}{l}\text { 5-g I want young people to be interested in the work } \\
\text { of traditional crafts in Bali }\end{array}$ \\
\hline
\end{tabular}

about three minutes. The interview contents included gender, age, residence, items purchased, the purpose of the purchase, and the items' appeal point. The interviewer asks them why they want to buy a traditional craft until he knew the reason.

\section{Results and discussion}

\subsection{Results of interviews for craftsman involved in the tradition in Bali}

I conduct the interviews for a total of 4 people on August 28 and August 30, 2019. The subjects are two wood-carvers and two painters living in the Ubud area of Bali. The summary of answers is as Table 2.

The environment in which they were born decides to become a traditional craftsman. The reason is a family business. They understand the needs of tourists for both as souvenirs and as art. Most of them are thinking of continuing the family business. Furthermore, the difference between the painter's and the carver's consciousness is 
Table 2 Result of interview surveys - the common answers of the subjects

$\begin{aligned} & \text { 1. Motivation to become a craftsman } \\ & \text { became a craftsman as part of my life } \\ & \text { 2. How to acquire the skill }\end{aligned}$
$\begin{aligned} & 2 \text { art collseges, } 2 \text { recommendations from the people around } \\ & \text { 3. Vision for work }\end{aligned}$
$\begin{aligned} & \text { I am the heir to this family business. ( } 3 \text { persons) } \\ & \text { I want as many people as possible to work on traditional crafts } \\ & \text { I understand both business perspectives as souvenirs and crea- } \\ & \text { tive activity perspectives as an artist }\end{aligned}$
$\begin{array}{ll}\text { 4. Existence of work assistants } & \text { There is no discrimination between men and women } \\ \text { 5. Women's participation in work } & \text { I take pride in being a craftsman } \\ \text { 6. Enthusiasm for craftsmen } & \text { The inheritance of traditional craft continues in a small way }\end{array}$

their will to continue. The painters have a stronger intention to do this, while the carvers have the sense of a hobbyist. The reasons for this determination also include the following. There are many painters all over the painting village. There are only a few wood-carvers all over wooden carver village, but there used to be many woodcarvers in the villages.

\subsection{Questionnaire for wood-carvers and painters}

I conduct the questionnaire survey in August/September and December 2019, during the unscheduled Hindu religious activities in Bali. Responses are obtained from 103 respondents (males $=93$ and females $=10), 51$ in August/September and 52 in December. As the reliability analysis results, the Cronbach's Alpha coefficient is 0.724 , and it keeps the reliability for analyzing the data.

\subsubsection{Results of simple aggregate in the face sheet}

The detail of 103 respondents is 93 males and 10 females. 49 wood-carvers, 50 painters, and 4 other stone carvers; however, it excludes stone carving from this analysis because of the difference in the work between stone and wooden carving. The compositions of age are 9 for teens, 13 for $20 \mathrm{~s}, 8$ for $30 \mathrm{~s}, 45$ for $40 \mathrm{~s}$, 12 for $50 \mathrm{~s}, 12$ for $60 \mathrm{~s}, 2$ for $70 \mathrm{~s}, 2$ for unknown. About half of them are in $40 \mathrm{~s}$. Working as a craftsman is 8 for 1-3 years, 19 for 4-7 years, 9 for 8-10 years, 22 for 10-15 years, and 15 for 16-20 years. There are 30 people who are working for over 20 years. Regarding "continuation of the current work", 13 wood-carving craftsmen are "continue", and 33 are "quit". 33 painters are "continue", and 16 are "quit". Regarding the number of craftsmen who continue to work, there are more painters than wood-carving. 


\subsubsection{Detail of consciousness as a craftsman}

Mann-Whitney $U$ test is used to analyze the difference in answers between the two groups, "continuation and retired" and "wood-carving and painting". Also, to understand each group's detail, compare the groups' consciousness on six points: duration of work, skill, pride, needs by tourist, prospect, and spirit for traditional culture. Based on these results, "their thoughts on the maintenance and transmission of craftsmanship skills" are obtained.

Multiple regression analyses with the stepwise method for linear carries using SPSS. As shown in Table 1, this focuses on each group of questions from 2 to 5. The dependent variable is the one question within each group, and the independent variables are all the other questions within the groups. As a result, the model, which the coefficient of determination R2 is high enough, which the significant probability $(p<0.01)$ and VIF (Variance Inflation Factor) are within the standard value, was selected. The consciousness can grasp by comparing the numerical values of the partial regression coefficients. Besides, when used the stepwise method in multiple regression analysis, the same independent variable cannot be adopted to compare the thoughts of the two target groups. Usually, to compare with the same independent

Table 3 Differences of consciousness between the groups of "Continuation and Retirement" and "Woodcarving and Painting"-Result of Mann-Whitney $U$ test

\begin{tabular}{|c|c|c|c|c|c|c|}
\hline & \multicolumn{3}{|c|}{ "Continuation (A) and Retirement(B)" } & \multicolumn{3}{|c|}{ "Wood Carving (A) and Painting (B)" } \\
\hline & $\begin{array}{l}\text { Significance prob- } \\
\text { ability (both sides) }\end{array}$ & Avg. of (A) & Avg. of (B) & $\begin{array}{l}\text { Significance prob- } \\
\text { ability (both sides) }\end{array}$ & Avg. of (A) & Avg. of (B) \\
\hline Q2a & 0.962 & 5.3 & 5.2 & $0.002^{* *}$ & 4.6 & 5.7 \\
\hline $\mathrm{Q} 2 \mathrm{~b}$ & 0.640 & 4.9 & 5.2 & $0.029^{*}$ & 4.8 & 5.4 \\
\hline Q2c & 0.206 & 6.5 & 5.9 & $0.000^{* * *}$ & 5.3 & 7.1 \\
\hline Q2d & $0.000^{* * *}$ & 6.6 & 4.9 & $0.000^{* * *}$ & 4.6 & 7.0 \\
\hline Q2e & $0.023^{*}$ & 1.8 & 2.8 & $0.002^{* *}$ & 2.7 & 1.8 \\
\hline Q2f & $0.000^{* * *}$ & 7.4 & 6.3 & $0.000^{* * *}$ & 6.4 & 7.4 \\
\hline Q3a & $0.024^{*}$ & 5.0 & 4.4 & $0.000^{* * *}$ & 4.4 & 4.9 \\
\hline Q3b & 0.463 & 4.1 & 3.9 & 0.519 & 4.2 & 3.8 \\
\hline Q4a & 0.697 & 2.9 & 3.1 & $0.006^{* *}$ & 3.7 & 2.4 \\
\hline Q4b & $0.000^{* * *}$ & 2.4 & 4.1 & $0.000^{* * *}$ & 4.2 & 2.3 \\
\hline $\mathrm{Q} 4 \mathrm{c}$ & $0.000^{* * *}$ & 6.6 & 4.9 & $0.003^{* *}$ & 5.4 & 6.3 \\
\hline Q5a & 0.097 & 7.0 & 6.6 & $0.000^{* * * *}$ & 6.5 & 7.2 \\
\hline Q5b & $0.050^{*}$ & 7.3 & 6.8 & $0.002^{* *}$ & 6.8 & 7.4 \\
\hline Q5c & 0.304 & 4.8 & 4.5 & $0.030^{*}$ & 4.7 & 4.7 \\
\hline Q5d & $0.008^{* *}$ & 4.7 & 3.7 & 0.166 & 4.1 & 4.3 \\
\hline Q5e & $0.000^{* * *}$ & 7.1 & 5.6 & $0.000^{* * *}$ & 5.5 & 7.1 \\
\hline Q5f & $0.002^{* *}$ & 4.6 & 3.7 & $0.000^{* * *}$ & 3.4 & 4.9 \\
\hline Q5g & $0.000^{* * *}$ & 7.0 & 5.8 & $0.000^{* * *}$ & 5.6 & 7.3 \\
\hline
\end{tabular}

Mann-Whitney $U p<0.05^{*} p<0.01^{* *} p<0.001^{* * *}$ 
variable uses the forced input method, but it sometimes is that the degree of fitting to the obtained consciousness will not apply well. Therefore, in this case, the stepwise approach needs to get the optimal solution for each group's model.

\subsubsection{1 a. The differences of consciousness between the groups of "Continuation and Retirement" and "Wood-carving and Painting" Firstly, the Mann-Whitney $U$ test} finds the difference between the means between the two groups of "continuation and retirement" (Table3). The questions having a difference in consciousness $(p<0.001)$ are in the contents of Q2f, Q4c, Q5e, Q5g concerning their pride as craftsmen and Q2d concerning their skill. The averages in the group of "continuation" were all high than another. The continuing group has a higher consciousness about their pride and skill. Between the two groups of "Wood-carving and Painting" carry out the same test. The difference in consciousness $(p<0.001)$ is in all answers except Q3b (income for supporting their family) and Q5d (future prosper of traditional craft). The mean value of "Painting" group had 1.5 points higher than the "Wood-carving" group, and the mean value of 7 or higher (8 is the highest level) is Q2c and Q2d related to "pride in one's skill" and Q5e and Q5g related to "strong will to carry on tradition". These results suggest that the painting group had a more vital consciousness of maintaining their skills and traditions.

\subsubsection{2 b. Results of multiple regression analysis for each group of "continuation} and retirement" of craftsmen Multiple regression analysis with the stepwise linear method is conducted on 6 points: a period of work, skill, pride, needs by tourist, prospects, and spirit to traditional culture. For each group, I selected some models in which the coefficient of determination $R^{2}$ is high enough, and the significant probability $(p<0.01)$ and VIF (Variance Inflation Factor) are within the standard value.

I show the analysis results in the "continuation" group below (Table 4).

As a result of analyzing a dependent variable as "It should maintain the Bali tradition", the following view is obtained.

"It is necessary to preserve designs that express Balinese traditions with high skills while meeting the needs of foreigners regardless of the type of traditional crafts, and to increase the understanding of young people".

$$
\mathrm{y}=-0.37+0.49 \times 1+0.41 \times 2+0.22 \times 3+0.27 \times 4-0.51 \times 5-0.20 \times 6,
$$

$R^{2}=0.77 y:$ (Dependent variable) "It should maintain the Bali tradition".

$x 1$ : Q5b (Explanatory variable) Designs that represent traditional Bali.

$x 2$ : Q5g Increasing young people's understanding.

x3: Q2d Possessing high skills.

$x 4$ : Q5f Welcomes changes due to foreigner needs.

$x 5$ : Q1d Types of traditional crafts.

$x 6$ : Q4b Not responding to the needs of tourists.

As a result of analyzing a dependent variable as "great pride as craftsmen," the following view is obtained.

"To create traditional Balinese designs with high skills to meet the needs of tourists as souvenirs". 
Table 4 Results of multiple regression analysis — "Continuation” group

Group: "continuation"

Q1i: Dependent variable: "Period of working"

\begin{tabular}{lccllll}
\hline \multicolumn{2}{c}{$B$} & $S E B$ & $\beta$ & $t$ & Sig & VIF \\
\hline \multicolumn{2}{l}{ Explanatory variables } & & & & & \\
Q1_b & 0.09 & 0.01 & 0.83 & 6.28 & $* * *$ & 3.25 \\
Q3_a & 0.50 & 0.16 & 0.30 & 3.11 & $* * *$ & 1.75 \\
Q1_f & 1.19 & 0.48 & 0.33 & 2.50 & $*$ & 3.31 \\
Q4_a & 0.25 & 0.11 & 0.25 & 2.15 & $*$ & 2.44 \\
$F$ & 35.11 & & & & & \\
$R^{2}$ & $0.76^{* * *}$ & & & & & \\
\hline
\end{tabular}

Group: "continuation"

Q2d: Dependent variable: "High skill"

\begin{tabular}{|c|c|c|c|c|c|c|}
\hline & $B$ & $S E B$ & $B$ & $t$ & sig & VIF \\
\hline \multicolumn{7}{|c|}{ Explanatory variables } \\
\hline Q1_d & 0.70 & 0.20 & 0.40 & 3.46 & $* * *$ & 1.33 \\
\hline Q3_b & 0.42 & 0.12 & 0.42 & 3.57 & $* * *$ & 1.34 \\
\hline Q4_a & -0.37 & 0.11 & -0.43 & -3.42 & $* * *$ & 1.51 \\
\hline Q5_e & 0.35 & 0.15 & 0.25 & 2.33 & $* *$ & 1.17 \\
\hline$F$ & 13.96 & & & & & \\
\hline$R^{2}$ & $0.57^{* * * *}$ & & & & & \\
\hline
\end{tabular}

Group: "continuation"

Q2c: Dependent variable: "High pride"

\begin{tabular}{lrrrrrr}
\hline \multicolumn{2}{c}{$B$} & $S E B$ & $\beta$ & \multicolumn{1}{l}{ sig } & VIF \\
\hline \multicolumn{2}{l}{ Explanatory variables } & & & & & \\
Q4_b & -0.28 & 0.07 & -0.37 & -4.13 & $* * *$ & 1.26 \\
Q2_c & 0.46 & 0.08 & 0.58 & 6.03 & $* * *$ & 1.46 \\
Q5_f & -0.26 & 0.07 & -0.37 & -3.92 & $* * *$ & 1.44 \\
Q5_b & 0.40 & 0.11 & 0.35 & 3.61 & $* * *$ & 1.45 \\
Q2_b & 0.20 & 0.06 & 0.31 & 3.37 & $* * *$ & 1.35 \\
Q1_i & -0.25 & 0.10 & -0.25 & -2.52 & $* *$ & 1.56 \\
$F$ & 20.03 & & & & & \\
$R^{2}$ & $0.76^{* * *}$ & & & & &
\end{tabular}

Group: "continuation"

Q5f: Dependent variable: "Changeable tradition according to Needs"

\begin{tabular}{lrrrrrr}
\hline \multicolumn{2}{c}{$B$} & $S E B$ & $\beta$ & $t$ & sig & VIF \\
\hline \multicolumn{2}{l}{ Explanatory variables } & & & & & \\
Q1_d & 1.3 & 0.3 & 0.7 & 5.3 & $* * *$ & 2.2 \\
Q2_e & -1.0 & 0.2 & -0.5 & -4.1 & $* * *$ & 1.5 \\
Q5_e & 0.8 & 0.2 & 0.5 & 4.7 & *** & 1.6 \\
\hline
\end{tabular}


Table 4 (continued)

Group: "continuation"

Q5f: Dependent variable: "Changeable tradition according to Needs"

\begin{tabular}{lcccccc}
\hline & $B$ & $S E B$ & $\beta$ & $t$ & sig & VIF \\
\hline Q4_b & 0.4 & 0.1 & 0.4 & 3.3 & $* * *$ & 1.7 \\
Q2_d & -0.4 & 0.2 & -0.4 & -2.7 & $* * *$ & 2.3 \\
Q2_a & -0.3 & 0.1 & -0.3 & -2.6 & $* * *$ & 2.0 \\
Q1_b & 0.0 & 0.0 & 0.2 & 1.6 & $* * *$ & 2.1 \\
$F$ & 11.52 & & & & & \\
$R^{2}$ & $0.69^{* * *}$ & & & & & \\
\hline
\end{tabular}

Group: "continuation"

Q5d: Dependent variable: "Prosperity of future traditional crafts"

\begin{tabular}{lcccccc}
\hline & $B$ & $S E B$ & $\beta$ & $t$ & sig & VIF \\
\hline \multicolumn{2}{l}{ Explanatory variables } & & & & & \\
Q3_b & 0.3 & 0.1 & 0.3 & 2.6 & $* * *$ & 1.2 \\
Q5_e & 0.5 & 0.2 & 0.4 & 3.2 & $* * *$ & 1.1 \\
Q5_c & 0.4 & 0.2 & 0.3 & 2.4 & $* *$ & 1.3 \\
$F$ & 13.6 & & & & & \\
$R^{2}$ & $0.51^{* * *}$ & & & & & \\
\hline
\end{tabular}

Group: "continuation"

Q5e: Dependent variable: "the tradition of Bali should be maintained."

\begin{tabular}{|c|c|c|c|c|c|c|}
\hline & $B$ & $S E B$ & $\beta$ & $t$ & sig & VIF \\
\hline \multicolumn{7}{|c|}{ Explanatory variables } \\
\hline Q5_b & 0.5 & 0.1 & 0.4 & 4.7 & $* * *$ & 1.3 \\
\hline Q5_g & 0.4 & 0.1 & 0.4 & 4.4 & $* * *$ & 1.4 \\
\hline Q2_d & 0.2 & 0.1 & 0.3 & 2.9 & $* * *$ & 1.7 \\
\hline Q5_f & 0.3 & 0.1 & 0.4 & 3.7 & $* * *$ & 1.8 \\
\hline Q1_d & -0.5 & 0.2 & -0.4 & -3.2 & $* * *$ & 2.4 \\
\hline Q4_b & -0.2 & 0.1 & -0.3 & -2.9 & $* * *$ & 1.4 \\
\hline$F$ & 21.81 & & & & & \\
\hline$R^{2}$ & $0.77^{* * *}$ & & & & & \\
\hline
\end{tabular}

$$
y=3.46-0.28 \times 1+0.46 \times 2-0.26 \times 3+0.40 \times 4+0.20 \times 5-0.25 \times 6,
$$

$R^{2}=0.76 y$ : (Dependent variable) "high pride as craftsmen". $x 1$ : Q4b (Explanatory Variable) Not responding to the needs of tourists.

$x 2$ : Q2c High skills.

$x 3$ : Q5f Traditions that can be changed by tourists' needs.

$x 4$ : Q5b Designs that represent traditional Bali. 
$x 5$ : Q2b The items handled are not traditional crafts but just souvenirs.

$x 6$ : Q1i Duration as a craftsman.

Also, if the dependent variable is "The future of traditional crafts", "It will be prosperous if we keep the tradition alive, as it is currently prosperous and can support our families adequately".

If the dependent variable is "focusing on needs", "the craftsmen, with the support of their families, should handle the traditional handicrafts of the unique Balinese culture with a high level of pride, and the village should work together to meet the need for souvenirs".

To summarize the above results, "the group of continuing" think like this, "Currently, traditional crafts are prospering, so while maintaining the pride and skill of craftsmen, and meeting tourists' need, we should maintain Balinese unique traditional crafts culture".

It shows the results of the analysis in the "retirement" group below (Table 5).

As a result of analyzing a dependent variable as "Prosperity of future traditional crafts", the following view is obtained.

"Regardless of the period engaged as a craftsman, the traditional craft continues to prosper because it handles with pride and high skill".

$$
y=-0.53+0.64 \times 1-0.57 \times 2+0.32 \times 3+0.26 \times 4,
$$

$R^{2}=0.68 y$ : (Dependent variable) "Prosperity of traditional crafts for the future".

$x 1$ : Q5c Prosperity of current traditional crafts.

$x$ 2: Q1i period engaged as a craftsman.

$x 3$ : Q2d Owns high skills.

$x$ 4: Q2f High pride as a craftsman.

As a result of analyzing a dependent variable as "Period of working as a craftsman", the following view is obtained.

"I didn't know what the future holds for this job, but at that time, it suits me to work as a craftsman. The products I handled were not unique Balinese, but there was a need from tourists, and I was able to earn enough money".

$$
y=0.61+0.10 x 1+0.34 x 2-0.17 x 3+0.45 \times 4-0.29 \times 5-0.21 \times 6
$$

$R^{2}=0.84 y$ : (Dependent variable) "Period of working as a craftsman".

$x 1$ : Q1b (Explanatory variable) Age.

$x$ 2: Q3a Enough income.

$x 3$ : Q2a Dealing with unique traditional Balinese crafts.

$x 4$ : Q4a High need of tourists.

$x 5$ : Q5d High prospects for the future.

$x 6$ : Q4b Not responding to the needs of tourists.

Also, if the dependent variable is "I can change the style according to the needs of tourists", the result is obtained as follows, "They were not highly skilled, but they are making traditional crafts with a combination of the spirit of Bali in their village to meet the needs of tourists". If the dependent variable is "Want to preserve the tradition of Bali", the result is obtained as follows, "The prospects 
Table 5 Results of multiple regression analysis — "Retirement" group

Group: "retirement"

Q1i: Dependent variable: "Period of working"

\begin{tabular}{lcccccr}
\hline \multicolumn{2}{c}{$B$} & SE B & \multicolumn{1}{c}{$\beta$} & $t$ & sig & VIF \\
\hline \multicolumn{2}{l}{ Explanatory variables } & & & & & \\
Q1_b & 0.10 & 0.01 & 0.92 & 9.69 & $* * *$ & 2.41 \\
Q3_a & 0.34 & 0.13 & 0.20 & 2.66 & $* * *$ & 1.58 \\
Q2_a & -0.17 & 0.04 & -0.26 & -3.82 & $* * *$ & 1.29 \\
Q4_a & 0.45 & 0.10 & 0.45 & 4.27 & $* * *$ & 2.96 \\
Q5_d & -0.29 & 0.09 & -0.27 & -3.27 & $* * *$ & 1.84 \\
Q4_b & -0.21 & 0.07 & -0.23 & -2.93 & $* * *$ & 1.62 \\
$F$ & 37.79 & & & & & \\
$R^{2}$ & $0.84 * *$ & & & & & \\
\hline
\end{tabular}

Group: "retirement"

Q2c: Dependent variable: "High pride"

\begin{tabular}{lcccccr}
\hline \multicolumn{2}{c}{$B$} & SE B & $\beta$ & $t$ & sig & VIF \\
\hline \multicolumn{2}{l}{ Explanatory variables } & & & & & \\
Q2_d & 0.62 & 0.10 & 0.51 & 6.16 & $* * *$ & 1.31 \\
Q2_a & 0.29 & 0.06 & 0.39 & 5.06 & $* * *$ & 1.15 \\
Q5_b & 0.52 & 0.13 & 0.34 & 4.00 & $* * *$ & 1.41 \\
Q3_b & 0.19 & 0.09 & 0.16 & 2.11 & $* *$ & 1.03 \\
Q5_a & -0.30 & 0.15 & -0.16 & -1.97 & $*$ & 1.28 \\
$F$ & 29.83 & & & & & \\
$R^{2}$ & $0.78 * * *$ & & & & & \\
\hline
\end{tabular}

Group: "retirement"

Q2d: Dependent variable: "High skill"

\begin{tabular}{lcccccr}
\hline \multicolumn{2}{c}{$B$} & $S E B$ & $\beta$ & $t$ & sig & VIF \\
\hline \multicolumn{2}{l}{ Explanatory variables } & & & & & \\
Q2_c & 0.61 & 0.09 & 0.74 & 6.61 & $* * *$ & 1.72 \\
Q1_b & 0.05 & 0.01 & 0.50 & 4.68 & $* * *$ & 1.54 \\
Q5_d & 0.34 & 0.11 & 0.34 & 3.09 & $* * *$ & 1.62 \\
Q2_a & -0.12 & 0.07 & -0.20 & -1.72 & $* * *$ & 1.82 \\
$F$ & 23.23 & & & & & \\
$R^{2}$ & $0.68^{* * *}$ & & & & & \\
\hline
\end{tabular}

Group: "retirement"

Q5f: Dependent variable: "Changeable tradition according to Needs"

\begin{tabular}{rrrrrrr}
\hline & $B$ & $S E B$ & $\beta$ & $t$ & sig & VIF \\
\hline \multicolumn{2}{l}{ Explanatory variables } & & & & & \\
Q2_c & 0.3 & 0.1 & 0.5 & 4.6 & $* * *$ & 1.0 \\
Q5_a & 0.4 & 0.1 & 0.3 & 3.0 & $* *$ & 1.0 \\
\hline
\end{tabular}


Table 5 (continued)

Group: "retirement"

Q5f: Dependent variable: "Changeable tradition according to Needs"

\begin{tabular}{lllllll}
\hline & $B$ & $S E B$ & $\beta$ & $t$ & sig & VIF \\
\hline$F$ & 10.23 & & & & \\
$R^{2}$ & $0.48^{* * *}$ & & & & \\
\hline
\end{tabular}

Group: "retirement"

Q5d: Dependent variable: "Prosperity of future traditional crafts"

\begin{tabular}{lcccccc}
\hline \multicolumn{2}{c}{$B$} & $S E B$ & $\beta$ & $t$ & sig & VIF \\
\hline \multicolumn{2}{l}{ Explanatory variables } & & & & & \\
Q5_c & 0.6 & 0.1 & 0.5 & 5.2 & $* * *$ & 1.1 \\
Q1_i & -0.6 & 0.1 & -0.6 & -6.4 & $* * *$ & 1.3 \\
Q2_d & 0.3 & 0.1 & 0.3 & 3.4 & $* * *$ & 1.3 \\
Q2_f & 0.3 & 0.1 & 0.3 & 2.9 & $* * *$ & 1.1 \\
$F$ & 23.9 & & & & & \\
$R^{2}$ & $0.68^{* * *}$ & & & & & \\
\hline
\end{tabular}

Group: "retirement"

Q5e: Dependent variable: "the tradition of Bali should be maintained"

\begin{tabular}{|c|c|c|c|c|c|c|}
\hline & $B$ & $S E B$ & $\beta$ & $t$ & sig & VIF \\
\hline \multicolumn{7}{|c|}{ Explanatory variables } \\
\hline Q5_g & 0.6 & 0.1 & 0.6 & 5.5 & $* * *$ & 1.0 \\
\hline Q5_a & 0.4 & 0.1 & 0.3 & 2.5 & $* *$ & 1.0 \\
\hline$F$ & 19.80 & & & & & \\
\hline$R^{2}$ & $0.46^{* * * *}$ & & & & & \\
\hline
\end{tabular}

for traditional crafts are not bright, but there is the traditional spirit of Bali with its high skills. For this reason, they hope that young people will inherit it". If the dependent variable is "Owns high skill", the result is got as follows, "The future is promising if craftsmen have high skills". Overall, these results show that it is the retired group that has focused on meeting the needs of tourists while working with a high degree of skill and pride in their traditional crafts. And they want to pass on the skill and pride to the younger generation.

Comparing the results of the analysis of between "continuation and retirement", the differences in consciousness are considered. High skill and pride are a priority in the consciousness of both groups. The priority level is almost the same for both, but the "continuing" tend to be higher than "retirement". There is also a common desire for young people having interested in traditional crafts. Additionally, the "cause of retirement" for the retired group is that they have been very faithful to the tourists' 
needs and, therefore, have lost their job due to some need issues that they cannot get over.

\subsubsection{Results of multiple regression analysis for each group of "Wood-carving} and Painting" of craftsmen As mentioned above, it conducts multiple regression analyses with the stepwise method for linear on the same 6 points: a period of work, skill, pride, needs by tourist, prospects, and spirit to traditional culture. Some models, for which the coefficient of determination $R^{2}$ is high enough, and the significant probability $(p<0.01)$ and VIF (Variance Inflation Factor) are within the standard value, are selected for each group.

It shows the analysis results in the "Wooden carving" group below (Table 6).

As a result of analyzing a dependent variable as "Period of working as a craftsman", the following view is obtained.

"It is the age-fitting craftsmen who are involved in the traditional crafts that are currently prospering by responding to the needs of tourists".

$$
y=-3.22+0.11 \times 1+0.38 \times 2-0.20 \times 3+0.27 \times 4,
$$

$R^{2}=0.65 y$ : (Dependent variable) "Period of working as a craftsman".

$x 1$ : Q1b (Explanatory variables) Age.

$x 2$ : Q5c The current prosperity of traditional crafts.

$x 3$ : Q4c Preserving traditions without being influenced by the needs of tourists.

$x 4$ : Q5a The spirit of Balinese people lives on.

As a result of analyzing a dependent variable as "It should maintain Balinese tradition", the following view is obtained. "It should focus on enhancing the understanding of young people and maintaining Bali's traditional and unique design without being influenced by tourists' needs".

$$
y=-1.88+0.56 \times 1+0.22 \times 2+0.23 \times 3+0.02 \times 4+0.12 \times 5,
$$

$R^{2}=0.76 y$ : (Dependent variable) "The tradition of Bali should be maintained".

$x 1$ : Q5g (Explanatory variable) Enhances young people's understanding.

$x$ 2: Q5b Designs that represent traditional Bali.

$x 3$ : Q4c Preserving traditions without being influenced by the needs of tourists.

$x$ 4: Q1b Age.

$x 5$ : Q2a Dealing with unique traditional Balinese crafts.

Besides, if the dependent variable is "High pride as a craftsman", the result is as follows, "It can maintain an income while preserving traditional Balinese crafts". If the dependent variable is "Prosperity of future traditional crafts", the result is as follows, "This will be possible if young people can be interested in traditional crafts that are not the souvenirs that are currently prospering, and can support their families".

To summarize the above results, though the wooden carving group recognizes that it should preserve the traditional Balinese craft without influencing tourists' needs, the working period influenced by their age is only temporary. This result is understood because many of the wood-carving group had already retired as artisans $(n=33)$. 
Table 6 Results of multiple regression analysis-"Wood-carving" group

Group: "wood curving"

Q1i: Dependent variable: "Period of working"

\begin{tabular}{lcccccr}
\hline \multicolumn{2}{c}{$B$} & $S E B$ & $\beta$ & $t$ & sig & VIF \\
\hline \multicolumn{2}{l}{ Explanatory variables } & & & & & \\
Q1_b & 0.11 & 0.01 & 0.93 & 8.83 & $* * *$ & 1.38 \\
Q5_c & 0.38 & 0.17 & 0.22 & 2.21 & $*$ & 1.22 \\
Q4_c & -0.20 & 0.10 & -0.21 & -2.11 & $*$ & 1.30 \\
Q5_a & 0.27 & 0.14 & 0.19 & 1.88 & $*$ & 1.23 \\
$F$ & 20.35 & & & & & \\
$R^{2}$ & $0.65^{* * *}$ & & & & & \\
\hline
\end{tabular}

Group: "wood curving"

Q2c: Dependent variable: "High pride"

\begin{tabular}{lcccccr}
\hline \multicolumn{2}{c}{$B$} & $S E B$ & $\beta$ & $t$ & sig & VIF \\
\hline \multicolumn{2}{l}{ Explanatory variables } & & & & & \\
Q3_a & 0.89 & 0.22 & 0.47 & 4.04 & $* * *$ & 1.02 \\
Q5_e & 0.41 & 0.13 & 0.37 & 3.17 & $* * *$ & 1.02 \\
$F$ & 15.25 & & & & \\
$R^{2}$ & $0.41^{\text {*** }}$ & & & & \\
\hline
\end{tabular}

Group: "wood curving"

Q2d: Dependent variable: "High skill"

\begin{tabular}{lcccccr}
\hline \multicolumn{2}{c}{$B$} & $S E B$ & $\beta$ & $t$ & sig & VIF \\
\hline \multicolumn{2}{l}{ Explanatory variables } & & & & & \\
Q2_c & 0.46 & 0.08 & 0.62 & 5.92 & $* * *$ & 1.04 \\
Q1_b & 0.05 & 0.01 & 0.47 & 4.03 & $* * *$ & 1.28 \\
Q5_d & 0.25 & 0.11 & 0.26 & 2.23 & $*$ & 1.31 \\
$F$ & 17.27 & & & & & \\
$R^{2}$ & $0.54^{* * *}$ & & & & & \\
\hline
\end{tabular}

Group: "wood curving"

Q5f: Dependent variable: "Changeable tradition according to needs"

\begin{tabular}{lrrrrrr}
\hline \multicolumn{2}{c}{$B$} & $S E B$ & $\beta$ & $t$ & sig & VIF \\
\hline \multicolumn{2}{l}{ Explanatory variables } & & & & & \\
Q2_d & -0.46 & 0.11 & -0.42 & -4.09 & $* * *$ & 1.10 \\
Q2_a & -0.28 & 0.08 & -0.43 & -3.45 & $* * *$ & 1.62 \\
Q5_a & 0.36 & 0.15 & 0.27 & 2.42 & $*$ & 1.25 \\
Q3_b & 0.58 & 0.15 & 0.46 & 3.77 & $* * *$ & 1.54 \\
Q2_e & 0.22 & 0.09 & 0.23 & 2.30 & $*$ & 1.07 \\
Q5_d & -0.28 & 0.13 & -0.27 & -2.08 & $*$ & 1.71 \\
$F$ & 10.33 & & & & & \\
$R^{2}$ & $0.60^{* * *}$ & & & & & \\
\hline
\end{tabular}


Table 6 (continued)

Group: "wood curving"

Q5d: Dependent variable: "Prosperity of future traditional crafts"

\begin{tabular}{lcccccr}
\hline \multicolumn{2}{c}{$B$} & SE B & $\beta$ & $t$ & sig & VIF \\
\hline \multicolumn{2}{l}{ Explanatory variables } & & & & & \\
Q3_b & 0.43 & 0.15 & 0.34 & 2.85 & $* *$ & 1.43 \\
Q5_g & 0.25 & 0.11 & 0.25 & 2.32 & $*$ & 1.15 \\
Q5_c & 0.54 & 0.19 & 0.34 & 2.90 & $* *$ & 1.33 \\
Q4_a & 0.23 & 0.10 & 0.26 & 2.24 & $*$ & 1.33 \\
Q2_b & -0.17 & 0.08 & -0.23 & -2.08 & $*$ & 1.15 \\
$F$ & 18.03 & & & & & \\
$R^{2}$ & $0.56 * *$ & & & & & \\
\hline
\end{tabular}

group: "wood curving"

Q5e: Dependent variable: "the tradition of Bali should be maintained"

\begin{tabular}{lccllll}
\hline \multicolumn{2}{c}{$B$} & SE B & $\beta$ & $t$ & sig & VIF \\
\hline \multicolumn{2}{l}{ Explanatory variables } & & & & & \\
Q5_g & 0.56 & 0.08 & 0.59 & 7.16 & $* * *$ & 1.18 \\
Q5_b & 0.22 & 0.09 & 0.22 & 2.42 & $* *$ & 1.39 \\
Q4_c & 0.23 & 0.07 & 0.28 & 3.16 & $* *$ & 1.33 \\
Q1_b & 0.03 & 0.01 & 0.27 & 2.99 & $* *$ & 1.43 \\
Q2_a & 0.12 & 0.06 & 0.20 & 2.01 & $*$ & 1.80 \\
$F$ & 26.56 & & & & & \\
$R^{2}$ & $0.76^{* * *}$ & & & &
\end{tabular}

It shows the results of the analysis in the "Painting" group below (Table 7).

As a result of analyzing a dependent variable as "Own high skill", the following view is obtained.

"For the painting creation which has the spirit of Bali in, they are able to earn enough income with a high level of pride, supported by their own families. In the future, it should improve its understanding of young people".

$\mathrm{y}=-6.23+0.70 \times 1-+0.41 \times 2+0.81 \times 3+030 \times 4+0.13 \times 5+0.20 \times 6$,

$R^{2}=0.76 y$ : (Dependent variable) "Owns high skill".

$x 1$ : Q5g (Explanatory variable) Enhances young people's understanding.

$x$ 2: Q5a The spirit of Balinese people lives on.

$x 3$ : Q1f Support from family.

$x 4$ : Q3a Enough income.

$x 5$ : Q2a Dealing with unique traditional Balinese crafts.

$x 6$ : Q2f High pride as a craftsman. 
Table 7 Results of multiple regression analysis_- "Painting” group

Group: "art painting"

Q1i: Dependent variable: "Period of working"

\begin{tabular}{lccllll}
\hline \multicolumn{2}{c}{$B$} & $S E B$ & $\beta$ & $t$ & sig & VIF \\
\hline \multicolumn{2}{l}{ Explanatory variables } & & & & & \\
Q1_b & 0.06 & 0.01 & 0.54 & 5.23 & $* * *$ & 1.32 \\
Q2_b & 0.24 & 0.07 & 0.35 & 3.52 & $* * *$ & 1.22 \\
Q5_e & 0.27 & 0.09 & 0.29 & 3.06 & $* *$ & 1.11 \\
Q2_e & 0.21 & 0.08 & 0.27 & 2.63 & $* *$ & 1.28 \\
Q1_f & 0.66 & 0.36 & 0.19 & 1.84 & $*$ & 1.34 \\
$F$ & 16.23 & & & & & \\
$R^{2}$ & $0.66^{* * *}$ & & & & & \\
\hline
\end{tabular}

Group: "art painting"

Q2c: Dependent variable: "High pride"

\begin{tabular}{lclllll}
\hline \multicolumn{2}{c}{$B$} & $S E B$ & $\beta$ & $t$ & sig & VIF \\
\hline \multicolumn{2}{l}{ Explanatory variables } & & & & & \\
Q2_d & 0.52 & 0.11 & 0.56 & 4.63 & $* * *$ & 1.11 \\
Q1_a & 2.13 & 0.73 & 0.38 & 2.92 & $* * *$ & 1.26 \\
Q1_i & 0.27 & 0.13 & 0.27 & 2.10 & $*$ & 1.28 \\
$F$ & 10.66 & & & & & \\
$R^{2}$ & $0.42^{* * *}$ & & & & \\
\hline
\end{tabular}

Group: "art painting"

Q2d: Dependent variable: "High skill"

\begin{tabular}{lclllll}
\hline \multicolumn{2}{r}{$B$} & SE $B$ & $\beta$ & $t$ & sig & VIF \\
\hline \multicolumn{2}{l}{ Explanatory variables } & & & & & \\
Q5_g & 0.70 & 0.11 & 0.52 & 6.20 & $* * *$ & 1.20 \\
Q5_a & 0.41 & 0.10 & 0.33 & 3.87 & $* * *$ & 1.26 \\
Q1_f & 0.81 & 0.33 & 0.22 & 2.47 & $*$ & 1.37 \\
Q3_a & 0.30 & 0.10 & 0.24 & 2.97 & $* *$ & 1.17 \\
Q2_a & 0.13 & 0.05 & 0.23 & 2.56 & $* *$ & 1.36 \\
Q2_f & 0.20 & 0.09 & 0.19 & 2.17 & $*$ & 1.31 \\
$F$ & 22.20 & & & & & \\
$R^{2}$ & $0.76^{* * *}$ & & & & &
\end{tabular}

Group: "art painting"

Q5f: Dependent variable: "Changeable tradition according to needs"

\begin{tabular}{lrrrrrr}
\hline \multicolumn{2}{c}{$B$} & SE $B$ & $\beta$ & $t$ & sig & VIF \\
\hline \multicolumn{2}{l}{ Explanatory variables } & & & & & \\
Q1_j & -1.08 & 0.39 & -0.32 & -2.81 & $* * *$ & 1.09 \\
Q5_a & 0.64 & 0.19 & 0.40 & 3.29 & $* * *$ & 1.23 \\
Q2_b & 0.54 & 0.13 & 0.56 & 4.06 & $* * *$ & 1.61 \\
\hline
\end{tabular}


Table 7 (continued)

Group: "art painting"

Q5f: Dependent variable: "Changeable tradition according to needs"

\begin{tabular}{lcccccc}
\hline & $B$ & $S E B$ & $\beta$ & $t$ & sig & VIF \\
\hline Q1_i & -0.79 & 0.19 & -0.56 & -4.24 & $* * *$ & 1.47 \\
$F$ & 10.10 & & & & \\
$R^{2}$ & $0.48^{* * *}$ & & & & \\
\hline
\end{tabular}

Group: "art painting"

Q5d: Dependent variable: "Prosperity of future traditional crafts"

\begin{tabular}{lcccccc}
\hline \multicolumn{2}{c}{$B$} & SE B & $\beta$ & $t$ & sig & VIF \\
\hline \multicolumn{2}{l}{ Explanatory variables } & & & & & \\
Q5_c & 0.33 & 0.15 & 0.26 & 2.16 & $* *$ & 1.80 \\
Q2_d & 0.61 & 0.16 & 0.40 & 3.83 & $* * *$ & 1.38 \\
Q1_a & 3.08 & 0.98 & 0.33 & 3.15 & $* *$ & 1.40 \\
Q4_c & 0.37 & 0.11 & 0.38 & 3.42 & $* * *$ & 1.58 \\
Q2_b & -0.28 & 0.11 & -0.25 & -2.62 & $* *$ & 1.13 \\
Q2_a & 0.16 & 0.09 & 0.19 & 1.88 & $*$ & 1.27 \\
$F$ & 14.09 & & & & & \\
$R^{2}$ & $0.67 * *$ & & & & & \\
\hline
\end{tabular}

Group: "art painting"

Q5e: Dependent variable: "the tradition of Bali should be maintained"

\begin{tabular}{lcccccc}
\hline \multicolumn{1}{c}{$B$} & SE B & $\beta$ & $t$ & sig & VIF \\
\hline \multicolumn{2}{l}{ Explanatory variables } & & & & & \\
Q2_d & 0.47 & 0.12 & 0.48 & 3.86 & $* * *$ & 1.11 \\
Q5_c & 0.23 & 0.10 & 0.27 & 2.21 & $*$ & 1.11 \\
$F$ & 14.04 & & & & \\
$R^{2}$ & $0.38^{* * *}$ & & & & \\
\hline
\end{tabular}

${ }^{*} p<0.05,{ }^{* *} p<0.01,{ }^{* * *} p<0.001$

As a result of analyzing a dependent variable as "Prosperity of future traditional crafts", the following view is obtained.

"Gender is a concern, but the future will be prosperous if they maintain their traditional crafts with highly skilled, and it is not a souvenir, and needs do not influence that".

$$
y=-6.39+0.33 \times 1+0.61 \times 2+3.08 \times 3+0.37 \times 4-0.28 \times 5+0.16 \times 6,
$$

$R^{2}=0.67 y:$ (Dependent variable) "Prosperity of future traditional crafts".

$x 1$ : Q5c Current prosperity of traditional crafts.

$x 2$ : Q2d Owns high skills. 
x3: Q1a Gender.

$x 4$ : Q4c Preserving traditions without being influenced by the needs of tourists.

$x$ 5: Q2b Items handled are not traditional crafts but just souvenirs.

$x 6$ : Q2a Dealing with unique traditional Balinese crafts.

Besides, if the dependent variable is "Protection of Balinese individuality", the following view is obtained, "It should prosper with high skills". If the dependent variable is "Period of working as a craftsman", the following view is obtained, "At a certain age, they engage in traditional crafts, and their families support them, and the crafts as souvenirs keep in the village".

To summarize the above results, the painting group recognizes, "It is possible to make a living with their family regarding traditional crafts because the craftsmen have high skills and keep the demand as souvenirs".

Comparing the analysis results for the group "Wood-carving and Painting", the differences in consciousness are as follows. It is the same consciousness that they recognize their skills and pride to maintain the traditional crafts of Bali. However, The Wood-carving group has to close down the crafts business because it cannot respond to business needs despite all their efforts, so they think it better to keep the tradition regardless of the requirements. Their vision for wood-carving for the future move to young generation oriented. The painting group continues to create. Because of the constant income to live their life, they can adapt their painting style to meet the needs of tourists with their pride as craftsmen.

In short, there are two reasons whether it can continue craftsmen: The first is that it is a family business, and the second is to be able to have enough basic income and time to spare of pride to be able to meet the needs of tourists. In this survey, the painters' group was more conscious of their high level of skill and pride in preserving Balinese traditions. This point is probably because their business as craftsmen is going well.

\subsection{Results of interviews with tourists who purchased traditional crafts}

I conducted the interview survey on the Ubud market on August 27th, 2019. Tourists who purchase crafts at the traditional market are the subjects of the interview. The interviewer approaches the tourists shortly after they have purchased. All respondents are 9, including 4 in the $20 \mathrm{~s}$ of Westerners, 1 in the $20 \mathrm{~s}$ of Chinese, 2 in the $40 \mathrm{~s}$ of Westerners, and 2 in the $50 \mathrm{~s}$ of Westerners. Their purchases are a total of 9 wood-carving and 7 paintings. The most common items are 5 animals of woodcarving and 5 landscapes of painting.

The following are the summary of the attractions of crafts purchased by the tourists. As a supplementary note, the paintings are framing in hand-carved wooden carvings.

- Because it is cheap than buying in the home country.

- Because it is preferable the natural materials of the frame with sculpture.

- Because the fact that "made in Bali" itself.

- Because I like ethnic expressions. 
- Because I like wood materials.

The answers in this interview find that tourists who have purchased Balinese traditional crafts feel the attractions to the low price and the natural materials and ethnic culture. The results of this study show that both wood-carving and painting are popular with tourists. This point will also lead to the viewpoint of Weiler and Hall (1992) in 1.1, "Souvenir purchases by tourists are an opportunity to experience different cultures, and through this act, they can form a forum for social connection with different cultures". The purchasing behaviors of tourists toward wooden carving and painting crafts seemed to fit the ethnic tourism described by Weiler and Hall.

\section{Discussion and hypothesis validation}

Based on the results of an interview survey with craftsmen of traditional crafts in 6.1 , the common consciousness of craftsmen of wooden carving and painting is as follows. They become a craftsman because their family and village strongly influence their minds and feel a mission to live as a craftsman. They also understand both businesses as a souvenir and the position of creative activity as an artist. Each craftsman inherits their family business on a small scale. It seemed that painters have more incredible pride as craftsmen than wood-carvers. Based on the results, it sets the following items for the questions in the questionnaire of the consciousness: "Pride as a craftsman", "Supporting family", "Inheriting the family business", "Thoughts on creative activities", and "Thoughts on souvenir products" and so on.

Based on the results of the questionnaire survey on craftsmen of wooden carving and painting in 6.2, they recognize their high-level skills and pride regardless of whether they continue their craftsmanship or not. And they hope that young people would have an interest in traditional crafts. Besides, they are tolerant of changes in traditional craft styles in response to tourist needs if they can keep their life. Many of the wood-carving groups have already quit, and many of the painting groups are continuing. The reasons are the influence of their continuity in the village and the existence of a family business, and the business efforts to meet the needs.

According to the interview survey results with purchasers of traditional crafts in 6.3 , many young tourists in the $20 \mathrm{~s}$ also purchase crafts. It turns out that they buy not only because of the low price but also because of the attractiveness of Balinese natural made and ethnic culture. The results shows that both wooden carving and painting were popular with tourists. The results of the 6.2 questionnaire survey reveals that the wood-carving craftsmen in the Ubud area around this market are out of business and are few. However, while many wooden carvers in the area are out of business, it is contradictory that wood-carving products are popular and purchased by tourists. What is the reason for this? According to the interview for craftsmen later, the reason is that these wooden carvings are low-quality souvenirs with mass-produced. Wholesalers located outside the Ubud area of Bali use the low costs labor. Wood-carving products wholesaled by traditional craftsmen in Ubud 
are more expensive than these. In other words, the craft merchants purchase cheap, mass-produced wooden carving and sell them at higher prices. It gets the assumption like this, the purchase of affordable in mass-produced products those merchants do not buy the high-quality and expensive traditional crafts made in the Ubud area. It should not overlook that some of the products include the wooden carving of Javanese origin, and tourists sometimes mistakenly buy Made in Java woodwork as Made in Bali.

In this study, the hypothesis is that "Ethnic tourism, which attempts traditional culture as for sale to the tourist, does not satisfy the requirements in sustainable tourism development concerning realizing happiness in the society that hosts tourism". The results of the survey (6.2) show that the craftsmen involved in the creation of sculptures and paintings have a high degree of pride in being the inheritors of tradition, and this pride also coexists with meeting the need for souvenirs. And many wood-carving craftsmen have lost their job. But almost all craftsmen, including them, are highly motivated to pass on Balinese traditions to the younger generation. Even if it forced the craftsmen to quit, most of them recognize the value of craftsmanship and are willing to create if they can make a living. However, the perspective of thinking is different from between the business strategy and the preservation of tradition. Is it ok that traditional craftsmanship, which business strategies have defeated, be destined to quit the profession? This situation has not achieved sustainability in maintaining the livelihoods of the artisans, who also have a role to play in the transmission of traditional culture. It is also unclear whether the lost job of craftsmen leads to the happiness of craftsmen; there is no life security for it. These points suggest that the hypothesis of this study is accurate. As a souvenir business, there is nothing wrong with bringing home the traditional culture by the interest of tourists in ethnic tourism. However, the original tradition needs to be protected not to get mixed up with cheap imitations. For example, the presence of Native Hawaiians has made a significant contribution to ethnic tourism in the state of Hawaii, USA. The state of Hawaii provides free-charge homes and schools to protect the native Hawaiians who maintain the traditional lifestyle. With these examples, Bali has a task to learn from the cultural policies of developed countries and strengthen its policies to enhance the value of its traditions. For example, it needs to protect the portrait rights of works of art as a heritage and separate the sale place of the imitations of tradition. There is also a need to attach a certificate of authenticity to each piece of work to show that genuine traditional craftsmen made it and empower the traditional craftsmen themselves to point out imitations and impose penalties. It would also be necessary to enact a law that guarantees the life income of the craftsmen to be administered by an association supported by government and foundation rather than an individual.

Finally, I will describe the current efforts of traditional craftsmen to protect themselves from the closure of their businesses and the destruction of their traditional culture. In the Tegal Lalang area of Ubud, where I interviewed Mr. I Made Ada in chapter 3.2, his son is leading a discussion on the future of traditional crafts. The sons of the second generation, who have a large stock of traditional crafts and are in danger of going out of business, have gathered to form a community and attempt to find a way out of this problem. The craftsmen who were 
successful in the golden days of traditional crafts educate their children not to take over their unstable careers. They wanted their children to have a high level of education and secure work life. However, as their children grow up, the children begin to feel a sense of responsibility for inheriting the traditional craft. As a result of their discussions, they begin to offer a wood-carving program to tourists, where they can get an in-depth understanding of the traditions of the craft and expect to earn some money. The program has been top-rated and attracted many Russians and Westerners, but due to COVID-19, it is no longer possible. Discussions are still ongoing regularly, and it expects future projects.

\section{Declarations}

Conflict of interest The author declare that have no conflict of interest.

\section{References}

Boorstin DJ (1962) The image; or, what happened to the American dream. Am Hist Rev 68(4):1076-1078

Bruner ME (2004) Culture on tour: ethnographies of travel. University of Chicago Press, Chicago

Greenwood DJ (1982) Cultural authenticity. Cult Surv Q 6(3):27-28

Hobsbawm E, Ranger T (1983) The invention of tradition, press of the University of Cambridge (Translation book: Keiji M (1992) Tsukurareta dento). Kinokuniya, Japan

Kayoko I (2004) Representation of "Ourselves" by echnic minorities in tourism: from the case of hilltribes in Northern Thiland. NUCB J Econ Inf Sci 49(1):215-240

Kazuya H (2013) New perspective for tourism study: from the viewpoint of tourist experience. Tour Stud Rev 1(1):19-34

Kelly JD (1997) A politics of virtue: hinduism, sexuality, and counter colonial discourse in fiji. J Am Oriental Soc 23(4)

Kenta O (2019) Jizokukanou na kankou seisaku no arikatani kansuru chousa kenkyu. PRI Rev 72:76-119

Klieger PC (1990) Close encounters: intimate tourism in Tibet. Cult Surviv Q 14(2):38-41

Mac Cannel D (1976) The tourist: a new theory of the leisure class. University of California Press, Berkeley ((1999))

McKean PF (1973) Cultural involution: tourists, balinese, and the process of modernization in an anthropological perspective. Ph.D dissertation, Brown University

Mubashar H (2011) The concept of globalization and how this has impacted on contemporary muslim understanding of ummah. J Glob Stud 2(2):145-159

Nezar A (2001) Consuming tradition, manufacturing heritage: global norms and urban forms in the age of tourism. Psychology Press

Nezar A (2004) The end of tradition? Routledge

Pariwisata dan Dinamika Kebudayaan Lokal, Nasionaldan Global. Denpasar; PT Upada Sastra

Quoted in Michel Picard (1990) Cultural tourism in Bali: cultural performances as tourist attraction. Cornell University Press; Southeast Asia Program Publications at Cornell University, Indonesia No. 49, 37-74. DOI: https://doi.org/10.2307/3351053

Shinji Y (2001) Kanko Jinruigaku. Shinyo sha, Tokyo

Smith VL, Hiroshi M (1991) Hosts and guests: the anthropology of tourism. Keiso shobo, Tokyo, pp 235-256

Toshiharu I (2002) Baritou geijutu wo tukutta otoko. Heibonsha shinsho

United Nations World Tourism Organization (UNWTO) (2004) Indicators of sustainable development for tourism destinations: a guidebook 
Yoshinori M (2011) A study on culture as tourism object in ethnic tourism. J Toho Gakuen 40(1):19-33

Publisher's Note Springer Nature remains neutral with regard to jurisdictional claims in published maps and institutional affiliations.

\section{Authors and Affiliations}

\section{Yoko Mayuzumi ${ }^{1}$}

$\triangle$ Yoko Mayuzumi

mayuzumi@bunkyo.ac.jp

1 Bunkyo University, 5-6-1 Hanahata, Adachi-ku, Tokyo 121-0061, Japan 